\title{
SUCCESSFUL QUEST FOR A SECOND SASKATCHEWAN NORTHERN PYGMY-OWL
}

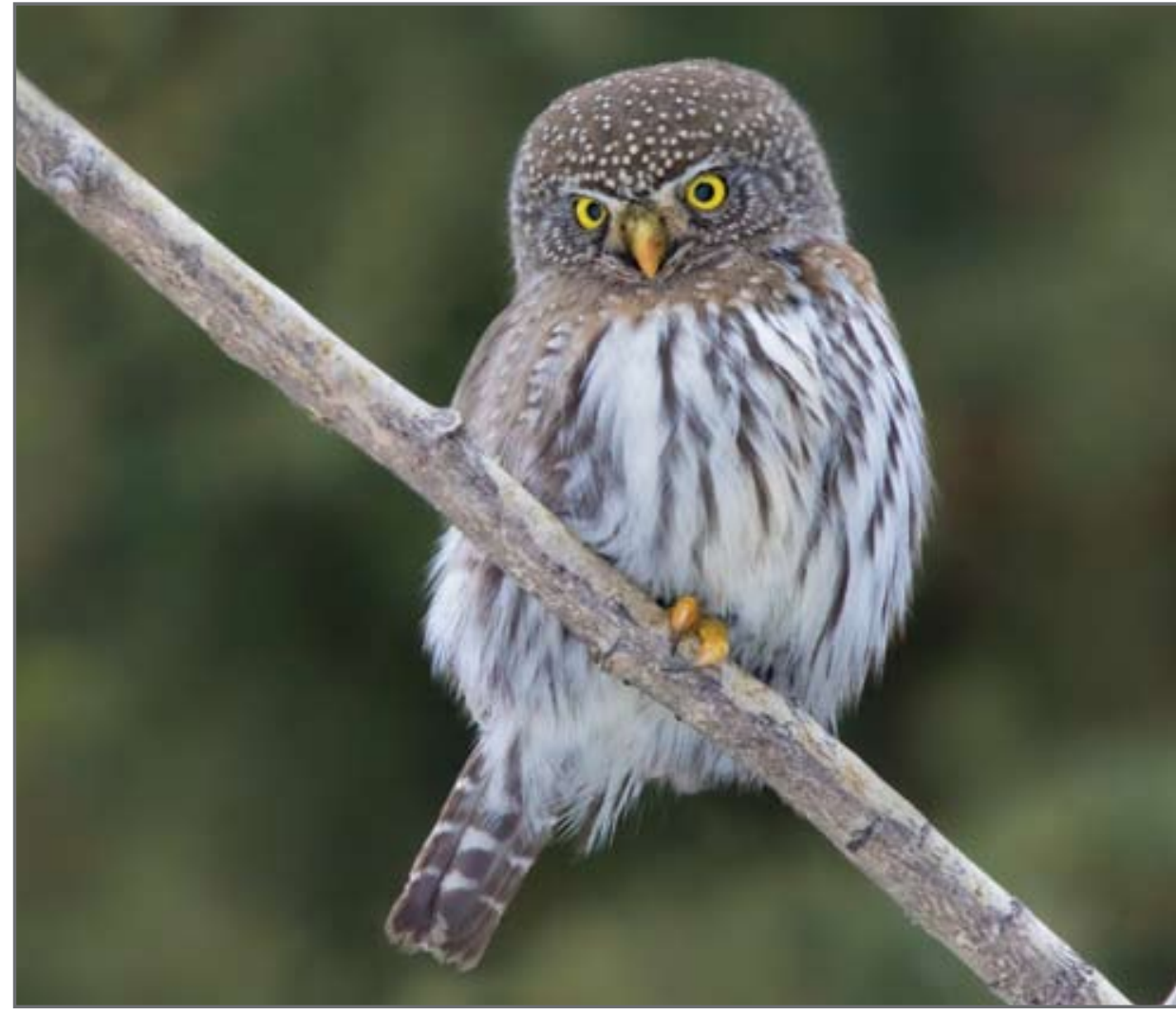

On January 28, 2017, a group returned to the area in which Stan and Jan Shadick found a Northern Pygmy owl and were able to locate one as well (possibly the same owl). Photo credit: Nick Saunders

Jan and Stan Shadick

903 Temperance St.

Saskatoon, SK S7N 0N3

\section{Reason for Quest:}

The Northern Pygmy-Owl

(Glaucidium gnoma) appears to be one of the most difficult birds to observe in Saskatchewan. We had previously heard them calling from a few sites in British Columbia and Arizona but even there had never managed to obtain a good view of this species.

\section{Incentive:}

We have enjoyed many winter owling expeditions organized by Marten Stoffel for the Saskatoon Nature Society. From time to time, he would pique our interest by suggesting that we should one day look for a Northern Pygmy-Owl in Saskatchewan, although his own attempts in far western Saskatchewan had failed.
He knew that at least one pygmyowl had been observed near Cold Lake, Alberta, which is immediately adjacent to Saskatchewan. Marten also commented that chickadees north of Green Lake, Saskatchewan would respond to his playback call of a Northern Pygmy-owl suggesting that they had probably encountered this species. Marten suggested that this species might be found some winter north of Meadow Lake Provincial Park.

\section{Research:}

Saskatchewan's only confirmed record of a Northern Pygmy-Owl was discovered by Richard Gruchy near La Ronge on October 12, 2014. The owl was observed and photographed by Christi Gruchy and Chris Giesbrecht from a distance of about $4 \mathrm{~m}$ before it flew to a nearby tree, and eventually departed. Details will be published in the upcoming two- volume "Birds of Saskatchewan." The eBird distribution map shows several records of Northern Pygmy-Owl in forested regions of Alberta north and west of Edmonton. When we were researching its known distribution in Alberta, the only eBird record farther east was a single owl photographed at Shaw Lake, about 100 km NW of Cold Lake, Alberta by Everett Hanna on November 28, 2016 (eBird checklist .S32775355).

\section{Plan:}

Since Jan and I were spending Christmas in Edmonton and at least one Northern Pygmy-Owl had been spotted this winter NE of Edmonton, we added an extra day to our return trip to combine a Christmas Bird Count (CBC) with a search for a Northern Pygmy-Owl along Highway 919 north of Meadow Lake Provincial Park. This highway runs north out of the park only 5 to $9 \mathrm{~km}$ east of the Alberta border. It is used to service some oil wells north of the park. Because the B\&B in Pierceland, Saskatchewan was not available, we chose to spend the night before our quest at a motel in Cold Lake, Alberta.

\section{The Quest:}

We had breakfast at the motel at 08:00 h (07:00 h Alberta time) on December 27, 2016 and then drove to Pierceland, Saskatchewan and then north along Highway 21 into Meadow Lake Provincial Park and turned onto Highway 919. We brought a bluetooth speaker for the cellphone so that we could play the owl's call from the Audubon Birds app on my cellphone in hopes that a pygmy-owl might respond.

Our first three stops along Pierce Lake produced in turn a single chickadee; a Hairy Woodpecker and a few Black-capped Chickadees; and 
a pair of Gray Jays. None appeared interested in our playback of the owl's call. About 10:00 h, we reached the Cold River, the southern edge of our Martineau River CBC that we now begun. At this stop, about four Boreal Chickadees came out of the woods to investigate the playback of our owl call.

During the next three hours, we slowly drove north along Highway 919 to its northern limit. At the Martineau River crossing and at a few other stops, we had Gray Jays and Boreal Chickadees come out of the woods to investigate the playback of the owl's call.

At about 13:00 h, we made a stop for lunch along the return trip. After playing the owl's call, several Gray Jays plus a small group of Boreal Chickadees and two Red-breasted Nuthatches immediately responded, quite agitated, flying from bush to bush, seemingly trying to find the source of the sound. Here we heard a single toot similar to the call of the owl following each playback. However, we did not find any owl. Might a jay have imitated an owl call?

About 14:00 h, at the kilometre 36 marker on Highway 919, our playback immediately attracted a mob of Gray Jays and Boreal Chickadees, two Blue Jays and, to our delight, an American Three-toed Woodpecker. The woodpecker was quickly forgotten when we heard a series of single toots exactly matching the pygmy-owl's call on our Audubon Bird app. It came from a cluster of mainly spruce trees about 100 m east of the road. We were nearly certain that this sound must be coming from the target of our quest and walked quickly toward the source of the toots. The flock of Boreal Chickadees and Gray Jays had now moved to this location and were creating quite a noisy ruckus, with four jays calling from the top of an aspen.

Below the jays, an amazing, incredibly tiny owl, less than half as large as a Gray Jay was perched facing me. It had the shape of an owl but with a rectangular tail jutting out at an angle quite unlike that of any other owl. Except for its tiny beak, the shape of this bird reminded me more of a puffbird from Panama than any typical Saskatchewan owl. Through my $10 \times 42$ Swarovski binoculars, the owl was gray-brown with tiny white dots on its forehead. Its chest was dark and its belly had widely spaced vertical stripes. Its eyes were yellow.

The owl then flew to the top of a spruce above us where Jan was able to find it. From the rear, its strange tail was barred with white horizontal stripes. Its back was dark with white spots. The bird then flew to another tree where Jan got a better look.

I then took out my cellphone but the phone instantly switched off. Thinking that the phone's battery was too low, I ran back to the car to get the scope and Jan's phone to try for a photo. Unfortunately, the owl flew away and we were not able to hear or see this amazing owl again. After checking Google maps at home, I would suspect that this spot is at 54.69997 degrees north latitude and 109.84862 degrees west longitude.

For the remainder of the afternoon, we searched along the "East-West" road within the count circle for any other owls. We thought the habitat looked promising for Northern Hawk Owls or Great Gray Owls but could not find any. The first-ever Martineau River CBC yielded 70 individuals of 11 species.

We think we were very, very lucky to find our Saskatchewan Northern Pygmy-Owl on December 27. As Marten Stoffel often states, "you need a horseshoe" (for luck).

Because northwestern Saskatchewan north of Meadow Lake Provincial Park is sparsely settled and has not been extensively birded, we wonder whether this second Saskatchewan sighting was a chance one-time visitor or whether the actions of other bird species might indicate

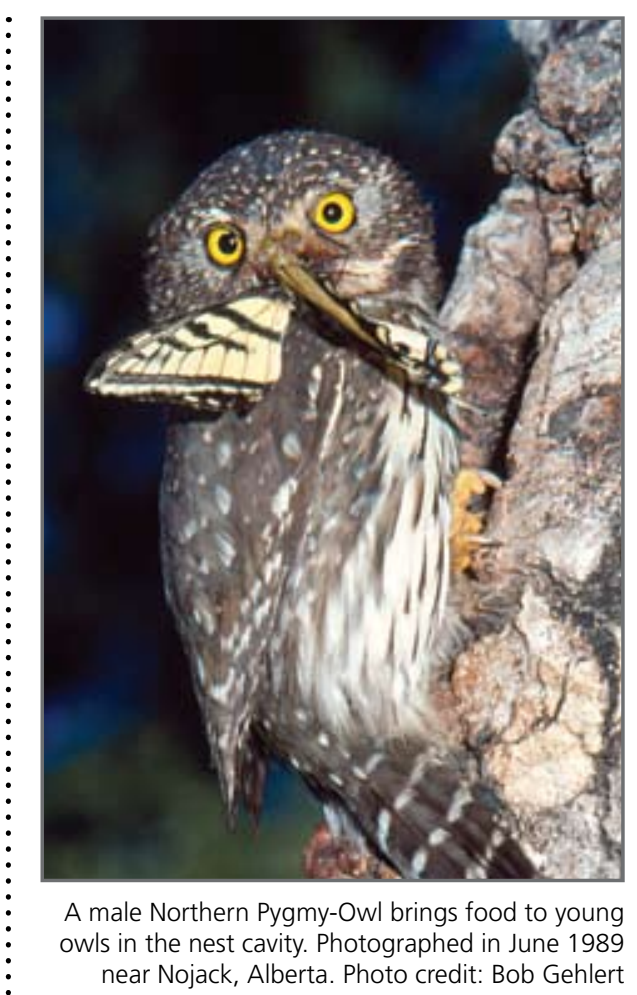

that a few more Northern Pygmy-Owls visit in winter. Jan thought that we should call our pygmy owl the Q-bird, because its small body resembled a capital Q and because the bird was "sooooo Qute!"

\section{Advice:}

1) Organize a group and take at least two vehicles along Highway 919. Although there was a single tire track, we saw no soul north of the mouth of the Cold River for the entire day. Cellphone coverage was spotty and we might have been up the creek if we had encountered any car problems beyond the reach of cellphones.

2) Bring a cellphone app plus a speaker to broadcast the call. Note that the owl did not fly toward us in response to playback. Presumably, it just started calling from its perch when we played its call.

3) Bring a working camera and a cellphone to record any owl hoots.

4) Plan to spend the nights before and after your search at the Pierceland $\mathrm{B} \& \mathrm{~B}$. It is a very long drive home from Pierceland. After a brief stop in Battleford, it was almost midnight when we made it home. 